Article

\title{
Chemical Composition and Antioxidant Properties of Juniper Berry (Juniperus communis L.) Essential Oil. Action of the Essential Oil on the Antioxidant Protection of Saccharomyces cerevisiae Model Organism
}

\author{
Martina Höferl ${ }^{1, *}$, Ivanka Stoilova ${ }^{2}$, Erich Schmidt ${ }^{1}$, Jürgen Wanner ${ }^{3}$, Leopold Jirovetz ${ }^{1}$, \\ Dora Trifonova $^{2}$, Lutsian Krastev ${ }^{4}$ and Albert Krastanov ${ }^{2}$ \\ 1 Department of Pharmaceutical Chemistry, Division of Clinical Pharmacy and Diagnostics, \\ University of Vienna, Vienna 1090, Austria; E-Mails: info@artandfragrance.de (E.S.); \\ leopold.jirovetz@univie.ac.at (L.J.) \\ 2 Department Biotechnology, University of Food Technologies, Plovdiv 4002, Bulgaria; \\ E-Mails: wstoilowa@yahoo.com (I.S.); dora.trifonova@gmail.com (D.T.); \\ a_krastanov@uft-plovdiv.bg (A.K.) \\ 3 Kurt Kitzing Co., Wallerstein 86757, Germany; E-Mail: juergen.wanner@kurtkitzing.de \\ 4 University Laboratory for Food Analyses, University of Food Technologies, Plovdiv 4002, Bulgaria; \\ E-Mail: loutcian@abv.bg \\ * Author to whom correspondence should be addressed; E-Mail: martina.hoeferl@univie.ac.at; \\ Tel.: +43-1-4277-55555; Fax: +43-1-4277-855555.
}

Received: 11 December 2013; in revised form: 26 January 2014 / Accepted: 28 January 2014 / Published: 24 February 2014

\begin{abstract}
The essential oil of juniper berries (Juniperus communis L., Cupressaceae) is traditionally used for medicinal and flavoring purposes. As elucidated by gas chromatography/flame ionization detector (GC/FID) and gas chromatography/mass spectrometry (GC/MS methods), the juniper berry oil from Bulgaria is largely comprised of monoterpene hydrocarbons such as $\alpha$-pinene $(51.4 \%)$, myrcene $(8.3 \%)$, sabinene $(5.8 \%)$, limonene $(5.1 \%)$ and $\beta$-pinene $(5.0 \%)$. The antioxidant capacity of the essential oil was evaluated in vitro by 2,2-Diphenyl-1-picrylhydrazyl (DPPH) scavenging, 2,2-azino-bis-3-ethylbenzothiazoline-6 sulfonic acid (ABTS) radical cation scavenging, hydroxyl radical $\left(\mathrm{OH}^{\circ}\right)$ scavenging and chelating capacity, superoxide radical $\left(\mathrm{O}_{2}{ }^{\circ}\right)$ scavenging and xanthine oxidase inhibitory effects, hydrogen peroxide scavenging. The antioxidant activity of the oil attributable to electron transfer made juniper berry essential oil
\end{abstract}


a strong antioxidant, whereas the antioxidant activity attributable to hydrogen atom transfer was lower. Lipid peroxidation inhibition by the essential oil in both stages, i.e., hydroperoxide formation and malondialdehyde formation, was less efficient than the inhibition by butylated hydroxytoluene (BHT). In vivo studies confirmed these effects of the oil which created the possibility of blocking the oxidation processes in yeast cells by increasing activity of the antioxidant enzymes superoxide dismutase (SOD), catalase (CAT), and glutathione peroxidase (GPx).

Keywords: juniper essential oil; Juniperus communis; GC/MS; antioxidant; Saccharomyces cerevisiae; antioxidant enzymes

\section{Introduction}

Reactive oxygen species (ROS) such as $\mathrm{H}_{2} \mathrm{O}_{2}, \mathrm{O}_{2}^{-}$and $\mathrm{OH}^{-}$are produced in the organisms during cellular metabolism. At lower concentrations they participate in cellular physiological reactions [1]. Their overproduction, however, largely determines cell survival. The ROS inactivation and removal depends on non-enzymatic and enzymatic protective mechanisms. Research on ROS-induced damage has shown that antioxidant production is genetically controlled in the cells [2]. The focus on antioxidants naturally contained in essential oils is directly related to their application aimed at the prevention of oxidative damage to biological systems by ROS. Low-molecular antioxidants can enhance organism stability under oxidative stress [3].

For centuries, juniper berries have been used in folk medicine for the treatment of opportunistic infections, as a spice for meat, and as flavor in the preparation of gin and raki [4,5].

The antioxidant activity of essential oils from different juniper berry species has been established in vitro [6]. Anti-radical activity depends on the oil components, i.e., their chemical nature and concentration [7-10]. Regardless of the differences in the composition of juniper berry essential oils, they are dominated by terpene hydrocarbons.

In many cases, the essential oil antioxidant activity cannot be attributed to the dominant compounds $\alpha$ - and $\beta$-pinene. These monoterpene hydrocarbons in juniper berry essential oil do not contribute to a significant inhibition of malondialdehyde formation [9]. The carriers of antioxidant properties in relation to lipid peroxidation in both its stages are $\alpha$ - and $\gamma$-terpinenes and, to a significantly lesser extent, their sesquiterpene analogues. This has been established both for juniper essential oils [7-9] and for pure terpene hydrocarbons: terpinolene, $\alpha$-terpinene and $\gamma$-terpinene [10]. Myrcene, $\alpha$ - and $\beta$-pinene only inhibit lipid peroxidation in the second stage; sabinene, limonene, $\alpha$-pinene, and myrcene demonstrate anti-radical activity in relation to DPPH radical $[11,12]$. The scavenging effect of $\mathrm{OH}^{*}$ and the protection of deoxyribose against degradation are mainly due to $\beta$-pinene and limonene [6]; the ${ }^{\circ} \mathrm{O}_{2}^{-}$neutralization is determined by germacrene-D [13]. The 10-membered ring system and the three double bonds acting as electron-rich centers in germacrene-D determine its anti-radical activity.

A number of studies have shown that the monoterpene components also contained in juniper essential oil enhance, through their antioxidant activity, the oxidative stress resistance of living 
organisms. Their antiradical activity affects the levels of the most important enzymes responsible for the neutralization of ROS: SOD, CATs, peroxidases, and glutathione transferase [12,14,15]. Saccharomyces cerevisiae is widely used for the better understanding of the cellular protection against ROS. Its enzymatic anti-ROS antioxidant protection has been well studied [16-20]. In this aspect, it was interesting to study the possibility of increasing the antioxidant protection of yeast cells using juniper berry essential oil and oxidant detoxification in vivo. The antioxidant properties of the essential oil both in vitro and in vivo are important for the overall evaluation of its action.

The aims of the present study were to investigate the chemical composition of the essential oil of juniper berries, to assess in vitro the antioxidant activity of juniper berry essential oil and to prove in vivo its preventive effect upon the oxidative damage in $S$. cerevisiae due to its action on the antioxidant enzymes SOD, CAT and GPx.

\section{Experimental Section}

\subsection{Materials}

Essential oil of juniper berries (Juniperus communis L., Cupressaceae) is a commercial product from Bulgaria. DPPH, $\beta$-Nicotinamide adenine dinucleotide 2-phosphate reduced tetrasodium salt (NADPH), L-Glutathione reduced, Glutathione reductase, Xanthine, Xanthine oxidase, Nitrotetrazolium blue chloride (NBT), Linoleic acid, Antioxidant assay kit, ABTS and dimethyl sulfoxide (DMSO) were obtained from Sigma-Aldrich, Co. (St. Louis, MO, USA). 2-Thiobarbituric (TBA) acid and 2-deoxy-D-ribose were obtained from Fluka (Darmstadt, Germany).

\subsection{GC/MS Analyses}

GC/FID and GC/MS analyses were carried out simultaneously on a Finnigan ThermoQuest TraceGC with a dual split/splitless injector, an FID detector and a Finnigan Automass quadrupole mass spectrometer. One inlet was connected to a $50 \mathrm{~m} \times 0.25 \mathrm{~mm} \times 1.0 \mu \mathrm{m}$ SE-54 fused silica column (CS Chromatographie Service, Langerwehe, Germany), the other injector was coupled to a $60 \mathrm{~m} \times$ $0.25 \mathrm{~mm} \times 0.25 \mu \mathrm{m}$ Carbowax $20 \mathrm{M}$ column (J \& W Scientific, Santa Clara, CA, USA). The two columns were connected at the outlet with a quartz $\mathrm{Y}$ connector and the combined effluents of the columns were split simultaneously to the FID and MS detectors with a short $(c a .50 \mathrm{~cm}) 0.1 \mathrm{~mm}$ ID fused silica restrictor column as a GC/MS interface. The carrier gas was helium 5.0 with a constant flow rate of $1.5 \mathrm{~mL} / \mathrm{min}$, injector temperature was $230{ }^{\circ} \mathrm{C}$, FID detector temperature $250{ }^{\circ} \mathrm{C}$, GC/MS interface heating $250{ }^{\circ} \mathrm{C}$, ion source at $150{ }^{\circ} \mathrm{C}$, EI mode at $70 \mathrm{eV}$, scan range $40-300$ amu. The following temperature program was used: $46{ }^{\circ} \mathrm{C}$ for $1 \mathrm{~min} ; 46{ }^{\circ} \mathrm{C}-100{ }^{\circ} \mathrm{C}$ at a rate of $5{ }^{\circ} \mathrm{C} / \mathrm{min}$; $100{ }^{\circ} \mathrm{C}-230{ }^{\circ} \mathrm{C}$ at $2{ }^{\circ} \mathrm{C} / \mathrm{min} ; 230{ }^{\circ} \mathrm{C}$ for $13.2 \mathrm{~min}$. Compounds were identified using Finnigan XCalibur 1.2 software [21] with MS correlations with NIST [22], Adams Essential Oils [23], MassFinder [24]) and our own library. Retention indices of reference compounds and from literature data [25], ESO 2000 upd. 2006 (Leffingwell \& Associates, GA, USA, 2006) were used to confirm peak data. Quantification of compounds was performed via peak area calculations of the FID chromatogram. 


\subsection{Antioxidant Activity in Vitro}

The DPPH scavenging effect was determined according to Mensor et al. [26] $1 \mathrm{~mL} 0.3 \mathrm{mM}$ ethanolic DPPH solution was added to $2.5 \mathrm{~mL}$ of the ethanolic juniper berry oil dilutions with different concentrations. The samples were kept at room temperature in the dark, and after $30 \mathrm{~min}$ the optical density of the samples, the blank or BHT as positive control was measured at $518 \mathrm{~nm}$ in comparison with ethanol.

The scavenging effect on radical cation $\mathrm{ABTS}^{\circ+}$ was determined using the Antioxidant Assay Kit (Sigma, CS0790, Saint Louis, MO, USA). Trolox, a water-soluble Vitamin E analog, serves as a standard or control antioxidant. BHT was used as positive control. One $\mathrm{mL}$ of the reaction mixture contained $10 \mu \mathrm{L}$ ethanolic dilution of the juniper berry oil $(1.5,3.125,6.25,12.5,25.0,50.0$ and $100 \mu \mathrm{g} / \mathrm{mL}$ ), Twenty $\mu \mathrm{L}$ solution of myoglobin, $150 \mu \mathrm{L}$ ABTS reagent (10 mL ABTS and $25 \mu \mathrm{L} 3 \%$ $\mathrm{H}_{2} \mathrm{O}_{2}$ ). The samples were kept at room temperature in the dark, and after 10 min the optical density was measured at $405 \mathrm{~nm}$.

Detection of $\mathrm{OH}^{\bullet}$ by deoxyribose assay was performed as described by Halliwell et al. [27] with minor changes. All solutions were freshly prepared. One $\mathrm{mL}$ of reaction mixture contained $28 \mathrm{mM}$ 2-deoxy-D-ribose (dissolved in $50 \mathrm{mM}$ phosphate buffer, $\mathrm{pH} 7.4$ ), $500 \mu \mathrm{L}$ of juniper berry oil dilution of various concentrations, $200 \mu \mathrm{M} \mathrm{FeCl}_{3}$ and $1.04 \mathrm{mM}$ EDTA $(1: 1 \mathrm{v} / \mathrm{v}), 10 \mathrm{mM} \mathrm{H}_{2} \mathrm{O}_{2}$ and $1.0 \mathrm{mM}$ ascorbic acid. After an incubation period of $1 \mathrm{~h}$ at $37{ }^{\circ} \mathrm{C}$, the extent of deoxyribose degradation was measured by the TBA reaction. One $\mathrm{mL}$ TBA reagent $(1 \% \mathrm{TBA}$ in $50 \mathrm{mM} \mathrm{NaOH})$ and $1.0 \mathrm{~mL}$ of trichloroacetic acid (TCA) were added to the reaction mixture and the tubes were heated at $100{ }^{\circ} \mathrm{C}$ for $20 \mathrm{~min}$. After cooling, the absorbance was read at $532 \mathrm{~nm}$ against a blank (containing only buffer and deoxyribose). Quercetin was used as a positive control.

Superoxide anions were generated in an enzymatic system (xanthine-xanthine oxidase) and assayed by the reduction of NBT. The former comprised a solution of $100 \mu \mathrm{M}$ xanthine, $60 \mu \mathrm{M}$ NBT in $0.1 \mathrm{M}$ phosphate buffer $(\mathrm{pH} 7.4)$ and $0.07 \mathrm{U} / \mathrm{mL}$ xanthine oxidase in a total volume of $1 \mathrm{~mL}$. Before the enzyme was added, $0.025 \mathrm{~mL}$ of ethanolic dilution of juniper berry oil $(100,140,160,180,200,240$ and $280 \mu \mathrm{g} / \mathrm{mL}$ ) were added to the samples. This mixture was incubated at $25{ }^{\circ} \mathrm{C}$ for $10 \mathrm{~min}$, and the optical density was read at $560 \mathrm{~nm}$ against a blank without the enzyme [28]. In order to check the inhibitory effect of juniper berry oil on xanthine oxidase activity, the enzyme was assayed by measuring the formation of uric acid from xanthine [28].

The percentage inhibition was calculated using the following Formula 1:

$$
I(\%)=100-100 \times \frac{A_{\text {sample }}}{\text { Acontrol }_{\text {col }}}
$$

The $\mathrm{IC}_{50}$ represented the concentration of the compounds that caused $50 \%$ inhibition of radical formation.

For evaluation of antioxidant activity in the linoleic acid model system, linoleic acid emulsions were prepared by mixing $0.285 \mathrm{~g}$ linoleic acid, $0.289 \mathrm{~g}$ Tween 20 as emulsifier and $50 \mathrm{~mL}$ phosphate buffer (50 mM, pH 7.2). The mixture was homogenized for $5 \mathrm{~min}$ according to Yen et al. [29]. The antioxidant was added at the final concentrations of $0.02 \%(\mathrm{wt} / \mathrm{v})$ of oil, BHT $0.01 \%$ was used as control. The mixture was incubated at $37{ }^{\circ} \mathrm{C}$ for 19 days. The course of oxidation was monitored by measuring the conjugated diene formation and TBA reactive substances (TBARS). The antioxidant 
activity at the end of the assay time was expressed as reduction percentage of peroxidation for each indicator. The control containing no antioxidant was $0 \%$. A higher percentage indicates a higher antioxidant activity. For determination of conjugated diene formation, aliquots of $20 \mu \mathrm{L}$ were taken at different intervals during incubation. After incubation, $2 \mathrm{~mL}$ of $60 \%$ methanol were added, and the absorbance of the mixture was determined at $233 \mathrm{~nm}$ [30]. A modified TBARS method was used to measure the antioxidant activity of oil in terms of inhibition on lipid peroxidation. $0.1 \mathrm{~mL}$ of sample was taken from the emulsion every day, and the following were sequentially added: the TBA-TCA solution (20 mM TBA in $15 \%$ TCA). The mixture was heated at $100{ }^{\circ} \mathrm{C}$ for $15 \mathrm{~min}$ and cooled at room temperature. After adding $2 \mathrm{~mL}$ of chloroform, the mixture was mixed and centrifuged at $2000 \mathrm{rpm}$ for $15 \mathrm{~min}$. The chloroform layer was separated and the absorbance of the supernatant was measured at $532 \mathrm{~nm}$ against a blank containing TBA-TCA solution [31].

For hydrogen peroxide scavenging activity, juniper berry oil dilutions (50, 100, 200, 400 and $800 \mu \mathrm{g} / \mathrm{mL}$, dissolved in $0.0125,0.025,0.05,0.1$ and $0.2 \mathrm{~mL}$ DMSO, respectively) were added to $1 \mathrm{~mL} 20 \mathrm{mM} \mathrm{H}_{2} \mathrm{O}_{2}$ in phosphate buffer $(0.1 \mathrm{M}, \mathrm{pH} 7.3)$. The initial and the final absorbance of the samples after an incubation period of $1 \mathrm{~h}$ at $25^{\circ} \mathrm{C}$ were measured at $240 \mathrm{~nm}$. Controls containing $20 \mathrm{mM} \mathrm{H} \mathrm{H}_{2} \mathrm{O}_{2}$ and the same DMSO volumes were prepared in a similar way. Hydrogen peroxide concentration was determined according to the Formula 2:

$$
c=\frac{\Delta A}{\varepsilon}
$$

$\Delta A=$ the difference in absorbance at the end and at the beginning of reaction; $\varepsilon=$ molar absorptivity of $\mathrm{H}_{2} \mathrm{O}_{2}=43.6 \mathrm{M}^{-1} \mathrm{~cm}^{-1}$.

\subsection{Antioxidant Activity in Vivo}

For the in vivo analyses, $S$. cerevisiae from the collection of the Department of Biotechnology at the University of Food Technologies, Plovdiv, were used. The strain was cultivated aerobically in a liquid medium ( $1 \%$ yeast extract, $1 \%$ Bacto-peptone, $2 \%$ glucose) for $48 \mathrm{~h}$ at $30{ }^{\circ} \mathrm{C}$. The cells were centrifuged (3000 $\left.\mathrm{min}^{-1}\right)$, washed with phosphate buffer $(50 \mathrm{mM}, \mathrm{pH} 7.0)$ and centrifuged again. Then, they were resuspended and diluted in phosphate buffer, $\mathrm{pH} 7.0$ resulting in a final optical density at $600 \mathrm{~nm}$ of 0.256 .

For the assays for antioxidant enzymes in yeast cells subjected to oxidative stress with hydrogen peroxide, $1 \mathrm{mM} \mathrm{H}_{2} \mathrm{O}_{2}$ (final concentration) was added to $1 \mathrm{~mL}$ of yeast suspension, which was then incubated for $16 \mathrm{~h}$ in the dark with periodic shaking. The yeast cells were centrifuged at $4000 \mathrm{~min}^{-1}$, washed twice with phosphate buffer $(50 \mathrm{mM}, \mathrm{pH} 7.0)$, centrifuged and resuspended in phosphate buffer to $1 \mathrm{~mL}$.

The reaction mixture for determination of the activities of antioxidant enzymes in the presence of various concentrations of the essential oil contained $1 \mathrm{~mL}$ suspension $\left(1.39 \times 10^{7} \mathrm{CFU} / \mathrm{mL}\right), 1 \mathrm{mM}$ $\mathrm{H}_{2} \mathrm{O}_{2}$ (final concentration) and juniper berry oil in different concentrations $(0.4,0.8,1.6,3.2$ and $4.0 \mathrm{mg} / \mathrm{mL}$ added in $0.01,0.02,0.04,0.08$ and $0.1 \mathrm{~mL}$ DMSO, respectively). Yeast suspension controls were also prepared using the same DMSO volumes. The samples were incubated for $16 \mathrm{~h}$ in the dark with periodic shaking. Then, the yeast cells were centrifuged at $4000 \mathrm{~min}^{-1}$ for oil and DMSO removal, washed twice with phosphate buffer $(50 \mathrm{mM}, \mathrm{pH} 7.0)$, centrifuged and resuspended in 
phosphate buffer to $1 \mathrm{~mL}$. This whole cell suspension was used for the evaluation of the enzymes superoxide SOD, CAT and GPx. The resultant enzyme activities were compared to those of $S$. cerevisiae cells not treated with oil. For evaluation of the protein content in yeast cells, the suspension was subjected to heat treatment for $20 \mathrm{~min}$ at $60{ }^{\circ} \mathrm{C}$. The resultant cell lysate was centrifuged at $4000 \mathrm{~min}^{-1}$ and the protein in the supernatant was determined according to the Lowry method [32].

SOD (EC 1.15.1.1) activity was assayed by the NBT test [33]. NBT was reduced to blue formazan by ${ }^{\circ} \mathrm{O}_{2}^{-}$, which has a strong absorbance at $560 \mathrm{~nm}$. The presence of SOD inhibited the reaction. The assay mixture consisted of sodium carbonate buffer $(\mathrm{pH}$ 10.2) containing xanthine, NBT, EDTA and $25 \mu \mathrm{L}$ of yeast suspension $\left(1.39 \times 10^{7} \mathrm{CFU} / \mathrm{mL}\right)$. The reaction was initiated by the addition of $50 \mu \mathrm{L}$ xanthine oxidase $(0.1 \mathrm{mg} / \mathrm{mL})$ and the mixture was incubated for $30 \mathrm{~min}$ at room temperature. The reaction was stopped by adding $6 \mathrm{mM}$ copper(II) chloride and the mixture was centrifuged at $1500 \mathrm{rpm}$ for $10 \mathrm{~min}$. The absorbance of blue formazan in the supernatants was measured at $560 \mathrm{~nm}$. One unit of SOD was defined as the enzyme amount causing 50\% inhibition in the NBT reduction. Activity was expressed as units per mg protein.

CAT (EC 1.11.1.6) activity was measured according to Carillo et al. [34]. The decomposition of $\mathrm{H}_{2} \mathrm{O}_{2} 3 \%(\mathrm{v} / \mathrm{v})$ was monitored by a decrease in absorbance at $240 \mathrm{~nm}$. The assay mixture contained $25 \mu \mathrm{L}$ of yeast suspension $\left(1.39 \times 10^{7} \mathrm{CFU} / \mathrm{mL}\right)$ in $50 \mathrm{mM}$ phosphate buffer $(\mathrm{pH} 7.0)$ at a final volume of $1.0 \mathrm{~mL}$. The samples were incubated for $2 \mathrm{~min}$ at $37{ }^{\circ} \mathrm{C}$ and the absorbance of the samples was monitored for $3 \mathrm{~min}$. One unit of CAT was defined as the enzyme amount causing decomposition of $1 \mu \mathrm{mol} \mathrm{H}_{2} \mathrm{O}_{2}$ in $1 \mathrm{~min}$.

GPx (EC 1.11.1.9) activity was assayed by the method of Paglia et al. [35]. The reaction mixture contained 0.1 M phosphate buffer ( $\mathrm{pH}$ 7.0), EDTA, glutathione, $\mathrm{NaN}_{3}, 1$ unit of glutathione reductase, $1.5 \mathrm{mM}$ NADPH and $25 \mu \mathrm{L}$ of yeast suspension $\left(1.39 \times 10^{7} \mathrm{CFU} / \mathrm{mL}\right)$. After incubation for $10 \mathrm{~min}$ at $37{ }^{\circ} \mathrm{C}, \mathrm{H}_{2} \mathrm{O}_{2}$ was added to each sample at a final concentration of $20 \mathrm{mM}$. The GPx activity was measured as the rate of NADPH oxidation at $340 \mathrm{~nm}$. One unit of GPx was defined as the enzyme amount causing oxidation of $1 \mu \mathrm{mol}$ NADPH in $1 \mathrm{~min}$.

CAT and GPx enzyme activities (EA) were expressed as units per mg protein $(\mathrm{U} / \mathrm{mg}$ ) and calculated according to the Formula 3:

$$
E A=\frac{\Delta A}{\varepsilon \cdot 3 \cdot m g}
$$

$\Delta A=$ the difference in absorbance at the end and at the beginning of reaction; $\varepsilon=0.0436 \mu \mathrm{mol}^{-1} \mathrm{~cm}^{-1}$ of $\mathrm{H}_{2} \mathrm{O}_{2}$ for $\mathrm{CAT} ; \varepsilon=6.3 \mu \mathrm{mol}^{-1} \mathrm{~cm}^{-1}$ of NADPH for $\mathrm{GPx} ; 3=$ reaction time (min).

\subsection{Statistical Analysis}

The experimental data analysis included approximation via fourth order polynomial dependences. For all cases, the plural correlation coefficient $R^{2}$ was determined. The concentration level corresponding to $50 \%$ of inhibition was calculated according to this approximated dependence for which $R^{2}$ was the maximum. The mathematical analysis of the data was carried out with MATHLAB [36]. All values of the enzyme activities are presented as mean $\pm \mathrm{SD}(n=3)$. The statistical differences between the activities of the treated and untreated yeast, and between oil-treated 
yeast and yeast-treated with DMSO were analyzed by Student's $t$-test. Differences showing $p \leq 0.05$ were considered statistically significant.

\section{Results and Discussion}

\subsection{Chemical Composition of Juniper Berry Oil}

Using GC/FID and GC/MS, 70 compounds were identified in the essential Juniperus communis L. oil (altogether, about $96 \%$ of the volatiles). As main components, the monoterpene hydrocarbons $\alpha$-pinene $(51.4 \%)$, myrcene $(8.3 \%)$, sabinene $(5.8 \%)$, limonene $(5.1 \%)$ and $\beta$-pinene $(5.0 \%)$ were found (Table 1). Concluding, the essential oil mainly comprises mono- and sesquiterpene hydrocarbons $(80.4 \%$ and $9.6 \%$, respectively); oxygenated derivatives are only minor constituents of this essential oil.

Table 1. Chemical composition of juniper berry oil.

\begin{tabular}{ccc}
\hline Substance & Retention Index & \% Area \\
\hline toluene & 771 & trace \\
hexanal & 800 & trace \\
$\alpha$-thujene & 933 & 0.9 \\
$\alpha$-pinene & 943 & 51.4 \\
$\alpha$-fenchene & 957 & 0.2 \\
camphene & 959 & 0.8 \\
thuja-2,4(10)-diene & 964 & 0.2 \\
sabinene & 981 & 5.8 \\
$\beta$-pinene & 988 & 5.0 \\
myrcene & 992 & 8.3 \\
$\delta$-3-carene & 1019 & 0.2 \\
$\alpha$-terpinene & 1024 & 0.1 \\
p-cymene & 1032 & 0.9 \\
limonene & 1037 & 5.1 \\
$\beta$-phellandrene & 1038 & 0.5 \\
(E)- $\beta$-ocimene & 1050 & 0.1 \\
$\gamma$-terpinene & 1065 & 0.2 \\
cis-sabinene hydrate & 1075 & 0.1 \\
terpinolene & 1096 & 0.4 \\
linalool & 1101 & 0.1 \\
perillene & 1104 & 0.1 \\
trans-sabinene hydrate & 1107 & 0.1 \\
$\alpha$-pinene oxide & 1111 & 0.1 \\
trans-p-menth-2-en- 1 -ol & 1131 & tr \\
campholen aldehyde & 1136 & 0.1 \\
trans-pinocarveol & 1154 & 0.3 \\
cis-verbenol & 1156 & 0.5 \\
borneol & 1180 & trace \\
\hline
\end{tabular}


Table 1. Cont.

\begin{tabular}{|c|c|c|}
\hline terpinen-4-ol & 1189 & 0.9 \\
\hline$p$-cymen-8-ol & 1193 & 0.2 \\
\hline$\alpha$-terpineol & 1201 & 0.2 \\
\hline myrtenol & 1208 & 0.1 \\
\hline myrtenal & 1210 & 0.2 \\
\hline verbenone & 1223 & 0.2 \\
\hline trans-carveol & 1228 & 0.2 \\
\hline carvone & 1256 & 0.1 \\
\hline methyl citronellate & 1260 & 0.1 \\
\hline undecan-2-one & 1294 & 0.1 \\
\hline bornyl acetate & 1298 & 0.3 \\
\hline methyl geranate & 1326 & trace \\
\hline citronellyl acetate & 1352 & 0.1 \\
\hline terpinyl acetate & 1359 & 0.1 \\
\hline$\alpha$-cubebene & 1366 & 0.6 \\
\hline geranyl acetate & 1382 & trace \\
\hline$\alpha$-copaene & 1397 & 0.5 \\
\hline$\beta$-elemene & 1409 & 0.7 \\
\hline$\alpha$-gurjunene & 1426 & 0.2 \\
\hline longifolene & 1438 & 0.1 \\
\hline$(E)-\beta$-caryopyhllene & 1447 & 2.0 \\
\hline$\gamma$-elemene & 1451 & 0.1 \\
\hline (E)- $\beta$-farnesene & 1461 & 0.3 \\
\hline$\alpha$-humulene & 1481 & 1.3 \\
\hline$\gamma$-muurolene & 1497 & 0.4 \\
\hline$\alpha$-amorphene & 1501 & 0.1 \\
\hline germacrene D & 1507 & 1.1 \\
\hline$\beta$-selinene & 1515 & 0.2 \\
\hline$\alpha$-muurolene & 1520 & 0.4 \\
\hline$\alpha$-selinene & 1521 & 0.2 \\
\hline$\gamma$-cadinene & 1538 & 0.5 \\
\hline$\delta$-cadinene & 1543 & 0.8 \\
\hline$\alpha$-cadinene & 1560 & 0.1 \\
\hline spathulenol & 1607 & 0.3 \\
\hline caryophyllene oxide & 1616 & 0.9 \\
\hline humulene epoxide II & 1643 & 0.5 \\
\hline$\tau$-muurol $+\tau$-cadinol & 1668 & 0.2 \\
\hline$\alpha$-cadinol & 1681 & 0.1 \\
\hline$m$-camphorene & 1964 & 0.2 \\
\hline$p$-camphorene & 2002 & 0.1 \\
\hline sum & & 96.0 \\
\hline
\end{tabular}

For comparison, Estonian juniper berry oil is also dominated by $\alpha$-pinene (47.9\%) [37], whereas the essential oil from Juniperus communis ssp. hemisphaerica is dominated by sabinene (25.1\%) and $\alpha$-pinene (13.6\%) [6]. Regardless of the domination of monoterpene compounds in the oils, there are 
differences in their quantitative composition due to a number of factors: geographical location, degree of ripeness and age, production method, etc. These differences underlie the individual biological properties of juniper berry essential oils.

\subsection{Antioxidant Activity of Juniper Berry Oil in Vitro}

DPPH assay was one of the in vitro tests used in this study to determine the ability of juniper berry oil components to act as hydrogen atom donors. It is usually regarded as a reaction of hydrogen atom transfer, but on the basis of the kinetic data, an electron transfer mechanism can also be considered for this assay $[38,39]$. Juniper berry essential oil was a weak DPPH radical reducer with $\mathrm{IC}_{50}$ value of $34.80 \mathrm{mg} / \mathrm{mL}\left(R^{2}=0.9896\right)$, compared to BHT $\left(\mathrm{IC}_{50}=4.414 \mu \mathrm{g} / \mathrm{mL}, R^{2}=0.999\right)$. Limonene in $10-50 \mu \mathrm{g} / \mathrm{mL}$ concentrations causes DPPH inhibition from $16 \%$ to $25 \%$ [12]. Emami et al. [6] established that $\gamma$-terpinene $(17.74 \%)$ showed antiradical activity in relation to DPPH radicals, while $\beta$-pinene had extremely low activity ( $0.96 \%)$, and of $\alpha$-pinene had no activity.

The antioxidant assay principle ABTS radical cation scavenging activity is the formation of a ferryl myoglobin radical from metmyoglobin and $\mathrm{H}_{2} \mathrm{O}_{2}$, which oxidizes the ABTS to produce a radical cation, $\mathrm{ABTS}^{\circ+}$. Antioxidants suppress the production of the radical cation in a concentration dependent manner and the color intensity decreases proportionally. Juniper berry essential oil showed a significant inhibitory effect of ABTS radicals $\left(\mathrm{IC}_{50}=10.96 \mu \mathrm{g} / \mathrm{mL}, R^{2}=0.9048\right)$, but again, BHT was considerably stronger $\left(\mathrm{IC}_{50}=0.0175 \mu \mathrm{g} / \mathrm{mL}, R^{2}=0.9996\right)$.

The results of the deoxyribose degradation inhibition also showed other action mechanisms of the antioxidants in juniper berry essential oil. During incubation of $\mathrm{Fe}^{3+}$-EDTA with $\mathrm{H}_{2} \mathrm{O}_{2}$ and ascorbic acid at $\mathrm{pH}$ 7.4, $\mathrm{OH}^{*}$ were formed, which was indicated by 2-deoxy-D-ribose degrading to fragments yielding a pink color when heated with TBA at low $\mathrm{pH}$ [27]. The juniper berry oil added to the reaction mixture removed the $\mathrm{OH}^{*}$ from the sugar and protected it against degradation. The effect of the inhibition of $\mathrm{OH}^{*}$ by juniper berry oil was expressed by $\mathrm{IC}_{50}=0.0066 \mu \mathrm{g} / \mathrm{mL}\left(R^{2}=0.9199\right)$, which was 931.18 times higher than that of quercetin $\left(\mathrm{IC}_{50}=6.15 \mu \mathrm{g} / \mathrm{mL}, R^{2}=0.996\right)$. In the absence of EDTA in the reaction mixture, some of the $\mathrm{Fe}^{3+}$ ions were able to form a complex with deoxyribose and participate in the formation of $\mathrm{OH}^{*}$. Only the molecules which can chelate $\mathrm{Fe}(\mathrm{III})$ and form a more stable complex with Fe(III) than ETDA and inactivate them can inhibit deoxyribose degradation. This action mechanism of juniper berry oil was proved in our studies. Juniper berry oil showed significant chelating capacity with $\mathrm{IC}_{50}$ of $1.083 \mu \mathrm{g} / \mathrm{mL}\left(R^{2}=0.9512\right)$, fully comparable to $\mathrm{OH}^{*}$ scavengers. The chelating capacity of the oil was 5.72 times stronger than that of quercetin with $\mathrm{IC}_{50}$ of $6.2 \mu \mathrm{g} / \mathrm{mL}$ $\left(R^{2}=0.999\right)$. Regarding the deoxyribose degradation assay, Emami et al. [6] established the strongest effect for pure compounds $\beta$-pinene and limonene. The Juniperus oblonga berry oil demonstrated the strongest anti-radical effect which, as the authors believe, may be attributed to the large amounts of $\beta$-pinene (20.8\%) in oil. Establishing the chelation of Fe(III) by juniper berry essential oil is important for our research using the $S$. cerevisiae model organism. The main source of $\mathrm{OH}^{\bullet}$ radical production was the Fenton reaction which occurred between $\mathrm{Fe}^{2+}$ and $\mathrm{H}_{2} \mathrm{O}_{2}$. Srinivasan et al. [40] showed that in yeast (wild-type and sod mutants), unlike in E. coli and mammals cells, most, if not all, EPR-detectable iron (free iron) was present in the Fe(III) state. On the other hand, excess superoxide 
could generate iron reduction by the Haber-Weiss reaction and, in turn, the ferrous ion could take part in the Fenton reaction.

Superoxide is biologically important since it can be decomposed to form stronger ROS such as singlet oxygen and $\mathrm{OH}^{*}$. Superoxide anions indirectly initiate lipid oxidation as a result of superoxide and hydrogen peroxide serving as precursors of singlet oxygen and $\mathrm{OH}^{*}$ [28]. Results from the in vitro experiments on the scavenging activity on ${ }^{\circ} \mathrm{O}_{2}{ }^{-}$and the inhibitory effect on xanthine oxidase activity proved that the juniper berry essential oil, introduced into the reaction mixture, scavenged ${ }^{\circ} \mathrm{O}_{2}{ }^{-}$radicals with an $\mathrm{IC}_{50}$ of $0.822 \mu \mathrm{g} / \mathrm{mL}\left(R^{2}=0.9805\right)$ in a similar manner as SOD but using mechanism different from the enzyme. As an antioxidant, this essential oil possesses a second mechanism of action-to inhibit the activity of xanthine oxidase, which led to decreased production of $\mathrm{O}_{2}{ }^{-}$radicals ( $\left.\mathrm{IC}_{50} 176.38 \mu \mathrm{g} / \mathrm{mL}, R^{2}=0.9938\right)$.

An important mechanism of antioxidant activity is the inhibition of linoleic acid oxidation. Polyunsaturated fatty acids such as linoleic acid are easily oxidized by atmospheric oxygen. This auto-oxidation leads to chain reactions with formation of conjugated double bonds and by-products such as aldehydes, ketones and alcohols. The unoxidized linoleic acid molecules have two unconjugated double bonds and no absorbance at $233 \mathrm{~nm}$. During the oxidation of lipid molecules, conjugated double bonds are formed, whereby lipid peroxides and hydroperoxides are produced, their absorbance at $233 \mathrm{~nm}$ increasing in relation to their concentration. Linoleic acid peroxidation caused by the formation of conjugated double bonds showed two absorbance maximums: on the third and the fifth day of incubation (control in this study) (Figure 1A). In the samples containing juniper berry oil in $0.01 \%(\mathrm{wt} / \mathrm{v})$ concentration, $23.63 \%$ inhibition was observed at the second peak of peroxide production, followed by a period of attenuation in the formation of lipid peroxides and hydroperoxides. Inhibition at the first peak is not observed.

The use of TBA reagent showed the presence of malonaldehyde - a secondary product of the linoleic acid peroxidation - which yielded a pink colored product with absorption maximum at $532 \mathrm{~nm}$. The control in this study showed four peaks in the formation of lipid peroxidation by-products: on the second, fifth, seventh and ninth day of the study (Figure 1B). The addition of juniper berry oil to the reaction emulsion reduced significantly the formation of lipid peroxidation by-products. On the second day of the process, $31.93 \%$ inhibition of lipid peroxidation was achieved; on the fifth day it was $35.12 \%$, on the seventh and ninth day, 35.88 and $68.51 \%$, respectively. Juniper berry oil inhibited to a larger extent the second of the two lipid peroxidation mechanisms, i.e., conjugated double bond formation and production of by-products of linoleic acid. It was less efficient than BHT in both processes of lipid peroxidation inhibition. Ruberto et al. [10] proved that $\alpha$ - and $\gamma$-terpinene and terpinolene had the highest antioxidant activity in both lipid peroxidation stages, the activity of $\alpha$ - and $\gamma$-terpinene being comparable to that of $\alpha$-tocopherol. $\alpha$-Pinene, sabinene and limonene exhibited weak activity only at the stage of by-product formation. The degree of lipid peroxidation inhibition by the juniper berry essential oil studied was determined by its composition. The oil was dominated by $\alpha$-pinene $(51.4 \%)$ and myrcene $(8.3 \%)$, with considerably lower concentration of terpinolene $(0.4 \%), \alpha$-terpinene $(0.1 \%)$ and $\gamma$-terpinene $(0.2 \%)$ as the carriers of higher antioxidant activity. 
Figure 1. Effect of juniper berry oil on (A) conjugated dienes and (B) TBARS in a linoleic acid/water emulsion system.
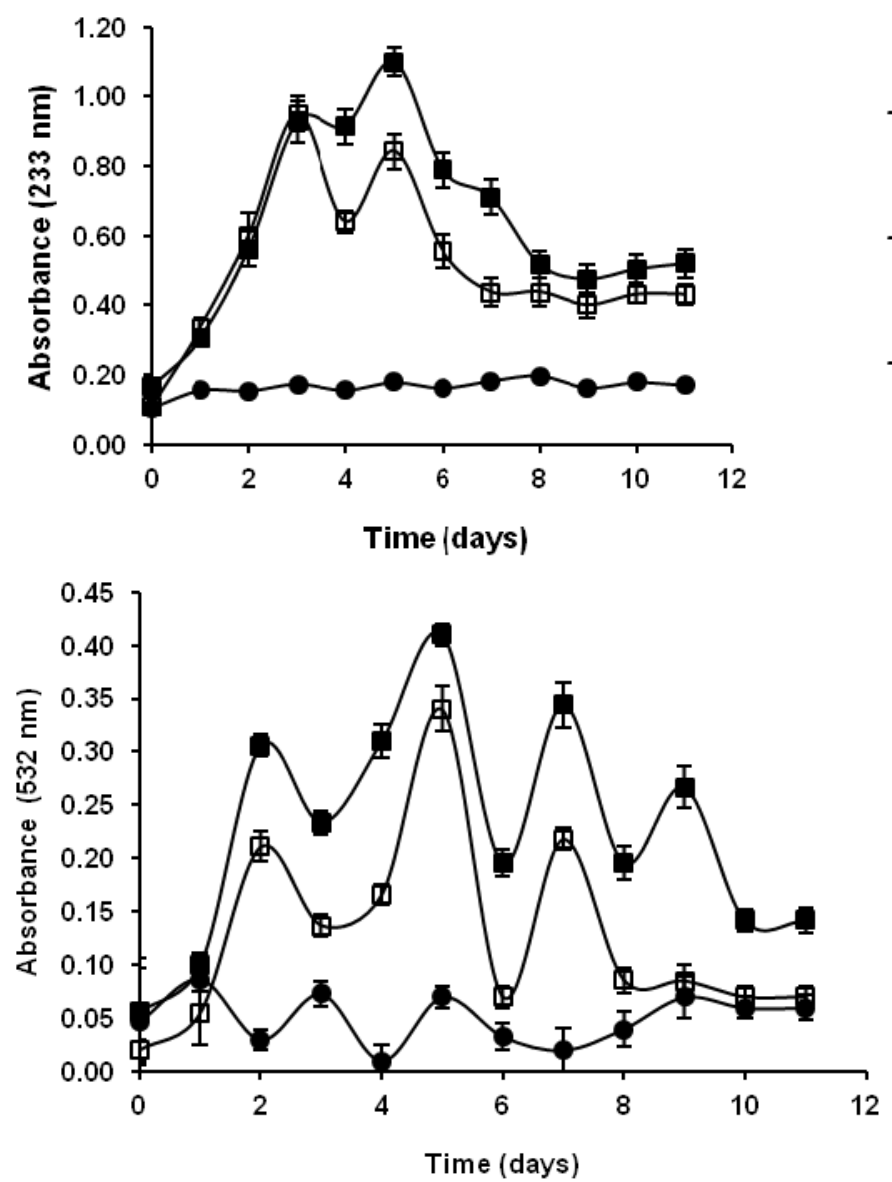

A

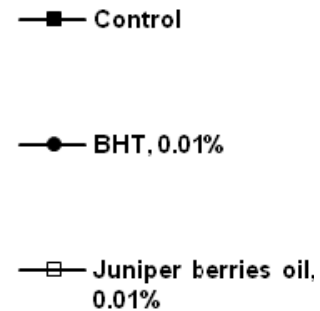

B

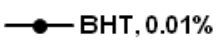

$\longrightarrow$ - Juniper berries oil, $0.01 \%$

Hydrogen peroxide scavenging activity of juniper berry oil was observed at concentrations from 50 to $800 \mu \mathrm{g} / \mathrm{mL}$ within the whole range studied (Figure 2). The initial concentration of $20 \mu \mathrm{M} \mathrm{H}_{2} \mathrm{O}_{2}$ decreased to $10.54 \mu \mathrm{M}$ in the presence of $800 \mu \mathrm{g} / \mathrm{mL}$ essential oil after $30 \mathrm{~min}$ of action. Thus, the oil imitated CAT action, the substrate for its action being $\mathrm{H}_{2} \mathrm{O}_{2}$. Under enzyme action, however, the enzyme remained unchanged whereas the juniper oil action in relation to hydrogen peroxide was probably due to the oxidation of some of the oil components. These results were consistent with $[8,41]$, which proved that cyclic monoterpene hydrocarbons $\alpha$ - and $\gamma$-terpinene (contained in juniper berry essential oil) were oxidized to the aromatic hydrocarbon p-cymene. The DMSO solvent used in increasing volumes had a weak effect on $\mathrm{H}_{2} \mathrm{O}_{2}$, the largest input volume of $0.2 \mathrm{~mL}$ reducing its concentration by $15.80 \%$. Gülçin et al. [42] also reported scavenging activity of clove oil on $\mathrm{H}_{2} \mathrm{O}_{2}$. The hydrogen peroxide scavenging property of essential oil is of great biological significance. Hydrogen peroxide is not a free radical but can generate the exceptionally strong $\mathrm{OH}^{*}$. Furthermore, $\mathrm{H}_{2} \mathrm{O}_{2}$ easily diffuses through mitochondrial membranes and can oxidize various compounds $[43,44]$.

The nine tests used for in vitro evaluation of juniper berry essential oil demonstrated its different action mechanisms. Its hydrogen atom (electron) donating capacity was proven by the DPPH assays and lipid peroxidation inhibition in both its stages. The investigated oil also had an electron yielding capacity-a mechanism underlying in $\mathrm{OH}^{\bullet}, \mathrm{ABTS}^{*+},{ }^{\cdot} \mathrm{O}_{2}^{-}$scavenging and $\mathrm{OH}^{\bullet}$ formation (chelating capacity). The antioxidant activity which was due to electron transfer made juniper berry essential oil a 
strong antioxidant. The antioxidant activity of the oil in descending order is: $\mathrm{OH}^{*}>$ xanthine oxidase inhibitory effects $>$ chelating capacity $>\mathrm{ABTS}^{{ }^{+}}>{ }^{\circ} \mathrm{O}_{2}{ }^{-}$. The antioxidant activity of the oil attributable to hydrogen atom transfer (DPPH assay) and lipid peroxidation inhibition were lower compared to BHT as standard. A number of researchers believe that the data on the antioxidant activity of essential oils or their components obtained according to different methods are practically incomparable. This is due both to the difference in the protocols used and to the different composition of the essential oils studied.

Figure 2. Hydrogen peroxide scavenging activity of juniper berry oil.

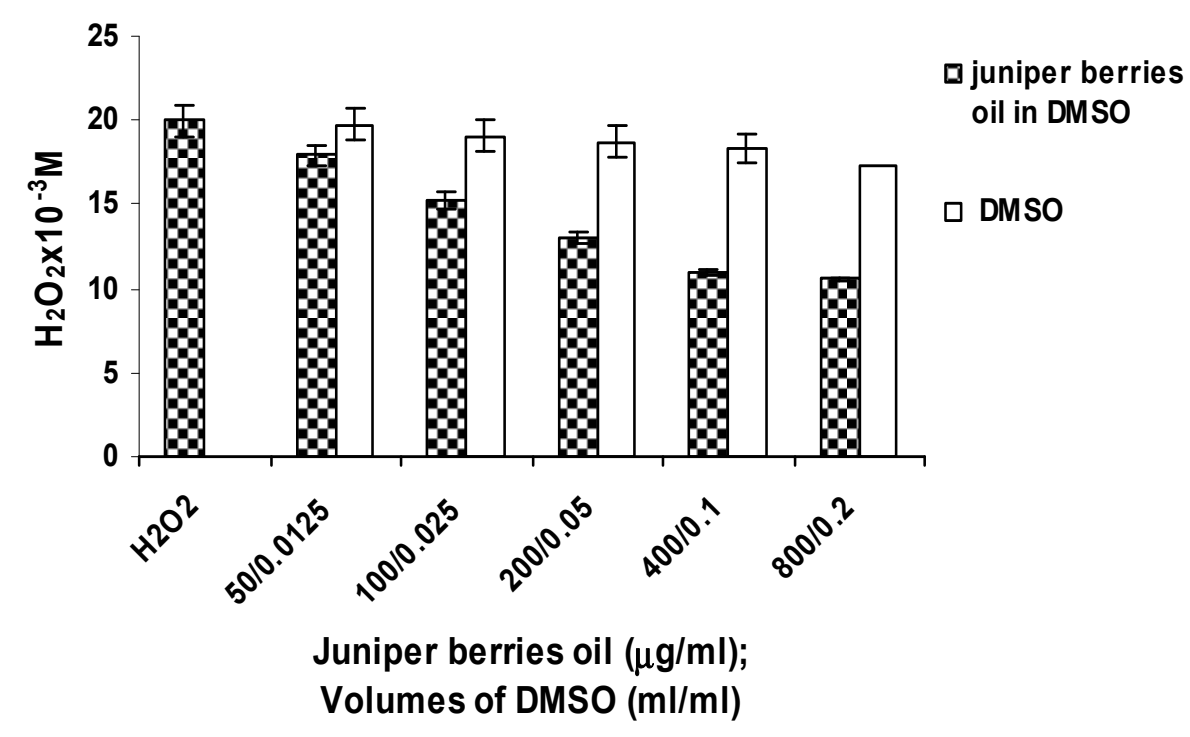

\subsection{Action of Juniper Berry Essential Oil on the Antioxidant Protection of Saccharomyces cerevisiae}

\section{Model Organism}

In this aspect, the essential oil effect on whole cells of wild $S$. cerevisiae strain was studied. It was evaluated in vivo on the antioxidant enzymes SOD, CAT and GPx (Figure 3). Molecular oxygen is assimilated as a substrate by the living cells and participates in different reactions catalyzed by the enzymes oxygenase, oxidase and hydroxylase. All these enzymes work interrelatedly, and the study of exogenous antioxidants upon certain enzymes in whole cells would provide an evaluation being as close as possible to the metabolic processes occurring in the cells. Oxygen assimilation is at the expense of partially reduced oxygen species, including the production of free radicals: ${ }^{\circ} \mathrm{O}_{2}{ }^{-}, \mathrm{H}_{2} \mathrm{O}_{2}$ and $\mathrm{OH}^{*}$. In the current experiment, enzyme levels of $S$. cerevisiae cell suspension were established before and after $16 \mathrm{~h}$ treatment with different essential oil concentrations. During that period, the cells were also subjected to starvation.

For SOD evaluation, in the whole yeast cells, the xanthine-xanthine oxygenase system generating ${ }^{\circ} \mathrm{O}_{2}^{-}$was used. The addition of whole cells only in the presence of xanthine caused xanthine oxidation under the effect of their own xanthine oxidase. Therefore, for the evaluation of SOD as control, the xanthine-xanthine-oxidase system and heat-inactivated cells (for elimination of the action of their own xanthine oxygenase) were used. The evaluation of CAT using whole cells was facilitated by the fact that the substrate for the action of this enzyme, i.e., $\mathrm{H}_{2} \mathrm{O}_{2}$ was non-ionized and easily diffused through the hydrophobic membranes of the mitochondrial biological membranes $[43,44]$. SOD participates in 
the dismutation of ${ }^{\circ} \mathrm{O}_{2}{ }^{-}$in hydrogen peroxide and molecular oxygen. CAT only decomposed $\mathrm{H}_{2} \mathrm{O}_{2}$, and yeast GPx acted both on $\mathrm{H}_{2} \mathrm{O}_{2}$ and organic hydroperoxides. The influence of oxidative stress $(1 \mathrm{mM}$ $\mathrm{H}_{2} \mathrm{O}_{2}$ ) on yeasts cells (Figure 3 ) could be demonstrated by increased levels of CAT $(342.2 \mathrm{U} / \mathrm{mg}$ ) and GPx (1.61 U/mg) activities, which were 1.58 and 1.32 times, respectively, higher compared to untreated yeast. SOD activity remained the same $(128.20 \mathrm{U} / \mathrm{mg})$.

Figure 3. Effect of juniper berry oil on (A) superoxide dismutase (SOD), (B) catalase $(\mathrm{CAT})$ and $(\mathbf{C})$ glutation peroxidase (GPx) activity in S. cerevisiae cells.

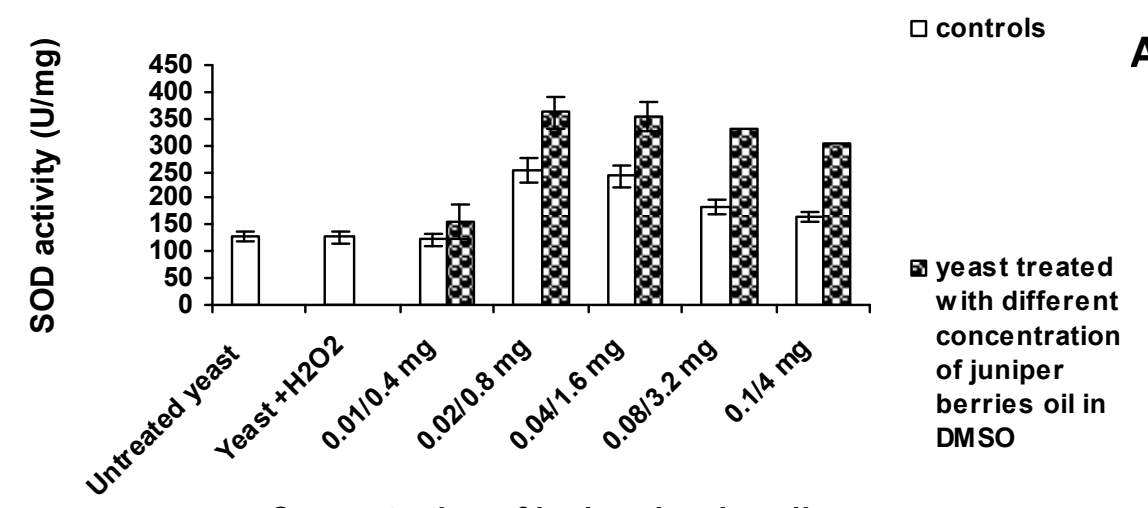

Concentration of juniper berries oil

(mg/ml)

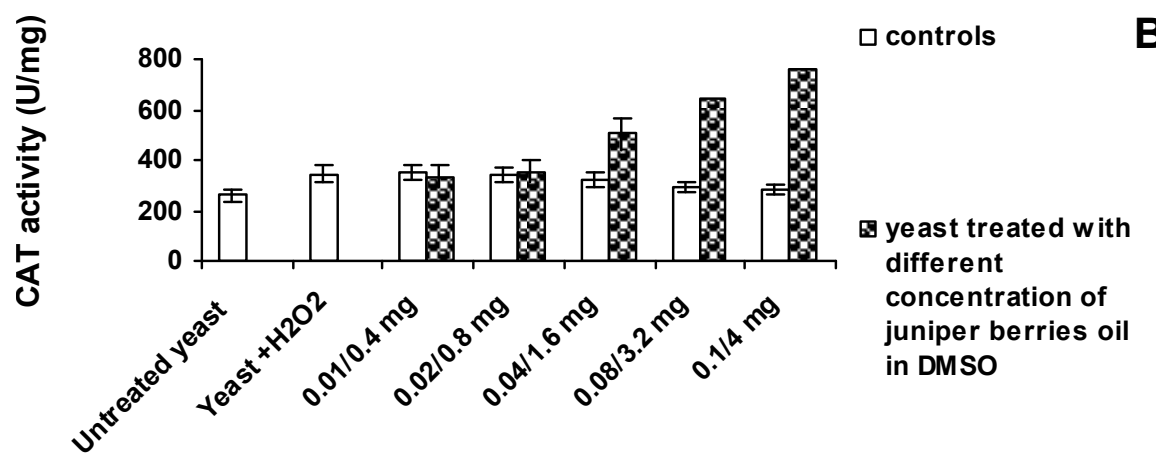

Concentration of juniper berries oil $(\mathrm{mg} / \mathrm{ml})$

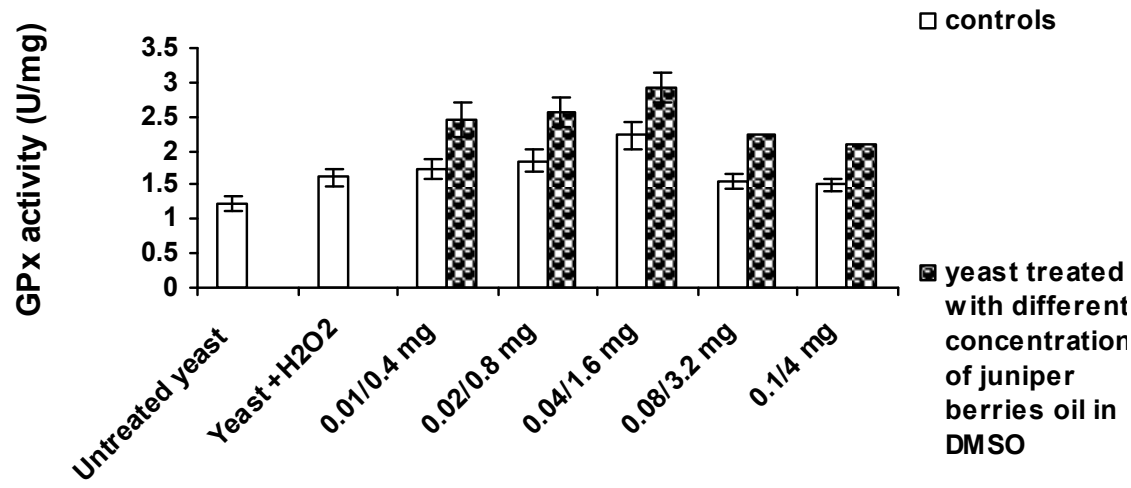

Concentration of juniper berries oil $(\mathrm{mg} / \mathrm{ml})$

The increase in the CAT activity in yeast cells treated with $\mathrm{H}_{2} \mathrm{O}_{2}$ can be explained by the inducible transcription of the CTT1 gene encoding CAT in $S$. cerevisiae cytoplasm [45,46]. It has also been proved that under oxidative stress, GPx genes of $S$. cerevisiae also encode phospholipid hydroperoxide GPx and that these enzymes protect yeast against phospholipid hydroperoxides [20,47]. 
In $S$. cerevisiae, the oxidative stress of $\mathrm{H}_{2} \mathrm{O}_{2}$ did not influence the expression of the genes, encoding $\mathrm{Cu} / \mathrm{Zn}$ SOD and Mn SOD [46]. Yeast cells treated with juniper berry essential oil exhibited direct dependence of the three enzymatic activities on the essential oil concentration (Figure 3).

In further experiments, it was examined if the level and concentration of the essential oil introduced into yeast suspension subjected to an oxidative stress, influenced in vivo the SOD activity in the yeast cells (Figure 3A). After 16-h oxidative effect and increasing concentrations of the essential oil from 0.4 to $0.8 \mathrm{mg} / \mathrm{mL}$, SOD activity increased respectively from 156.34 to $361.29 \mathrm{U} / \mathrm{mg}$. Introduction of higher concentrations of the essential oil $(1.6,3.2$ and $4.0 \mathrm{mg} / \mathrm{mL})$ caused a decrease in SOD activity to $304.84 \mathrm{U} / \mathrm{mg}(4 \mathrm{mg} / \mathrm{mL})$. However, this enzyme activity is still 2.38 times higher compared to the control (128.23 U/mg).

In contrast to SOD, the results for the CAT showed continual increase of the enzyme activity with increasing concentrations of the introduced essential oil (Figure 3B). The influence of the essential oil is most significant on the CAT activity in the cells at a concentration of $4.0 \mathrm{mg} / \mathrm{mL}(756.22 \mathrm{U} / \mathrm{mg})$. The resulting activity is 2.91 times higher than the activity of the cells not subjected to oxidative stress (260.03 U/mg) and 2.21 times higher than the activity of the cell subjected to oxidative stresses (342.42 U/mg).

Results for the GPx activity in the yeast cells (Figure 3C) showed that the highest activity of $2.92 \mathrm{U} / \mathrm{mg}$ can be achieved at a concentration of $1.6 \mathrm{mg} / \mathrm{mL}$ of the juniper berry essential oil. Below and above this concentration, GPx activity was lower. GPx activity reached at a concentration of $1.6 \mathrm{mg} / \mathrm{mL}$ was 2.39 times higher than the activity of the untreated yeast cells $(1.22 \mathrm{U} / \mathrm{mg})$, and 1.81 times higher than that in the experiment (yeast $\left.+\mathrm{H}_{2} \mathrm{O}_{2}\right)(1.61 \mathrm{U} / \mathrm{mg}$ ). The decrease in the GPx activity at concentrations of the essential oil above $1.6 \mathrm{mg} / \mathrm{mL}$ could be explained by the fact that, at those concentrations, CAT activity increases because of the same substrate activity. It was obvious that DMSO influenced the levels of the enzymes examined. Within the studied range, SOD and GPx are active only in the presence of the solvent DMSO, and these activities change in the presence of the essential oil. However, as absolute values, these activities are lower than those obtained in the presence of the essential oil. DMSO had the least impact on the CAT activities. Activities of SOD (Figure 3A), CAT (Figure 3B) and GPx (Figure 3C) of yeast treated with juniper berry were significantly $(p<0.05)$ different compared to controls (untreated yeast) and yeast treated with DMSO.

Under starvation conditions and treatment with juniper essential oil, yeast cells exhibited higher antioxidant capacity than the antioxidant protection of cells subjected to oxidative stress by $1 \mathrm{mM}$ $\mathrm{H}_{2} \mathrm{O}_{2}$. The maximum SOD, CAT and GPx activities were, respectively, 2.82, 2.21 and 1.81 times higher than the activities of the activities of those enzymes treated with $\mathrm{H}_{2} \mathrm{O}_{2}$. SOD is the first protection line against oxidative stress in living organisms [48]. The scavenging of ${ }^{\circ} \mathrm{O}_{2}{ }^{-}$which is a precursor of highly reactive $\mathrm{ROS}$ such as $\mathrm{OH}^{\bullet}$, is particularly important for organism adaptation under oxidative stress. Considering the fact that the expression of the genes encoding $\mathrm{Cu} / \mathrm{Zn}$ SOD and $\mathrm{Mn}$ SOD in $S$. cerevisiae is not inducible by oxidative stress [46], as our in vitro study proved that juniper berry essential oil introduced into reaction mixture is able to scavenge ${ }^{\circ} \mathrm{O}_{2}{ }^{-}$radicals and to inhibit xanthine oxidase, we can assume that the increasing SOD activity resulted from the action of juniper berry essential oil. We proved in vitro that juniper oil could degrade hydrogen peroxide similarly to CAT action (Figure 2). Monoterpene compounds are known to be able to penetrate cells [7] and therefore neutralize endogenous $\mathrm{H}_{2} \mathrm{O}_{2}$. The significant increase in the CAT and GPx activity in yeast 
cells in the presence of juniper essential oil and under starvation stress conditions may be due to inducible gene transcription [20,45-47] and probably to a larger extent to the CAT-like action of the oil components.

The enhanced antioxidant protection was indirect evidence of the change in the endogenous levels of $\mathrm{H}_{2} \mathrm{O}_{2}$ and other organic peroxides in this microorganism. Higher enzyme activities in the yeast cells meant better ability of the cells to degrade hydrogen peroxide, organic hydroperoxides and phospholipid hydroperoxides. Thus, it would follow that the level of these peroxides within the cells would be lower at higher enzyme activity. Roberto et al. [12] proved that a lower $\mathrm{H}_{2} \mathrm{O}_{2}$ endogenous level corresponded to a higher CAT and GPx activity in lymphocyte cells treated with the monoterpene compound limonene. If the increasing activity of these enzymes enables cells to neutralize the ROS, their decreasing activity should be considered as a decreasing ability of cells to neutralize them. The treatment with high concentrations of essential oils $(4 \mathrm{mg} / \mathrm{mL})$ probably induced the damage to S. cerevisiae. Parveen et al. [49] reported damages induced to S. cerevisiae. The authors found that the S. cerevisiae participating in ergosterol biosynthesis and assimilation, lipid metabolism, cell wall structure and function, and cellular transport were affected by $\alpha$-terpinene treatment.

\section{Conclusions}

In vitro antioxidant research of juniper essential oil proved the existence of several mechanisms which enabled radical scavenging, $\mathrm{H}_{2} \mathrm{O}_{2}$, the prevention of radical formation (chelating capacity, inhibitory effect on xanthine oxidase) and protection against lipid peroxidation. In vivo studies confirmed these effects of the oil which created the possibility of blocking the oxidation processes in yeast cells and enhanced their adaptivity to ROS. The biological effects of juniper berry essential oil in vivo were directly dependent on the concentrations applied. It is well known that ROS contribute to organism aging and the etiopathogenesis of various diseases. The proved ability of juniper berry essential oil to enhance adaptivity to ROS in vivo adds new details to the essential oil properties. These properties determine its potential for food additive production, an efficient way to improve people's health and quality of life. Furthermore, it expands its areas of application to perfumery, cosmetics, pharmacy and medicine.

\section{Conflicts of Interest}

The authors declare no conflict of interest.

\section{References}

1. Schopfer, P.; Plachy, C.; Frahry, G. Release of reactive oxygen intermediates (superoxide radicals, hydrogen peroxide, and hydroxyl radicals) and peroxidase in germinating radish seeds controlled by light, gibberellin, and abscisic acid. Plant Physiol. 2001, 125, 1591-1602.

2. Kim, Y.I.; Kim, H.J.; Kwon, Y.M.; Kang, Y.J.; Lee, I.H.; Jin, B.R.; Han, Y.S.; Cheon, H.M.; Ha, N.G.; Seo, S.J. Modulation of MnSOD protein in response to different experimental stimulation in Hyphantria cunea. Comp. Biochem. Physiol. 2010, 157, 343-350. 
3. Martorell, P.; Forment, J.V.; de Llanos, R.; Montón, F.; Llopis, S.; González, N.; Genovés, S.; Cienfuegos, E.; Monzó, H.; Ramón, D. Use of Saccharomyces cerevisiae and Caenorhabditis elegans as model organisms to study the effect of cocoa polyphenols in the resistance to oxidative stress. J. Agric. Food Chem. 2011, 59, 2077-2085.

4. Darwin, T. The Scots Herbal: The Plant Lore of Scotland; Birlinn Ltd.: Edinburgh, UK, 2008.

5. Hiller, K.; Löw, D. Juniperi Pseudo-Fructus. In Teedrogen und Phytopharmaka; Wichtl, M., Ed.; Wissenschaftliche Verlagsgesellschaft: Stuttgart, Germany, 2009.

6. Emami, S.A.; Javadi, B.; Hassanzadeh, M.K. Antioxidant activity of the essential oils of different parts of Juniperus communis. subsp. hemisphaerica and Juniperus oblonga. Pharm. Biol. 2007, 45, 769-776.

7. Misharina, T.A.; Samusenko, A.L. Antioxidant properties of essential oils from lemon, grapefruit, coriander, clove, and their mixtures. Prikl. Biokhimiia Mikrobiol. 2008, 44, 482-486.

8. Misharina, T.A.; Terenina, M.B.; Krikunova, N.I. Antioxidant properties of essential oils. Prikl. Biokhimiia Mikrobiol. 2009, 45, 710-716.

9. Wei, A.; Shibamoto, T. Antioxidant activities and volatile constituents of various essential oils. J. Agric. Food Chem. 2007, 55, 1737-1742.

10. Ruberto, G.; Baratta, M.T. Antioxidant activity of selected essential oil components in two lipid model systems. Food Chem. 2000, 69, 167-174.

11. Bua-in, S.; Paisooksantivatana, Y. Essential oil and antioxidant activity of Cassumunar ginger (Zingiberaceae: Zingiber montanum (Koenig) Link ex Dietr.) collected from various parts of Thailand. Kasetsart J. Nat. Sci. 2009, 43, 467-475.

12. Roberto, D.; Micucci, P.; Sebastian, T.; Graciela, F.; Anesini, C. Antioxidant activity of limonene on normal murine lymphocytes: Relation to $\mathrm{H}_{2} \mathrm{O}_{2}$ modulation and cell proliferation. Basic Clin. Pharmacol. Toxicol. 2010, 106, 38-44.

13. Karioti, A.; Hadjipavlou-Litina, D.; Mensah, M.L.K.; Fleischer, T.C.; Skaltsa, H. Composition and antioxidant activity of the essential oils of Xylopia aethiopica (Dun) A. Rich. (Annonaceae) leaves, stem bark, root bark, and fresh and dried fruits, growing in Ghana. J. Agric. Food Chem. 2004, 52, 8094-8098.

14. Van Lieshout, E.M.; Posner, G.H.; Woodard, B.T.; Peters, W.H. Effects of the sulforaphane analog compound 30, indole-3-carbinol, D-limonene or relafen on glutathione $S$-transferases and glutathione peroxidase of the rat digestive tract. Biochim. Biophys. Acta 1998, 1379, 325-336.

15. Sepici-Dincel, A.; Açikgöz, S.; Cevik, C.; Sengelen, M.; Yeşilada, E. Effects of in vivo antioxidant enzyme activities of myrtle oil in normoglycaemic and alloxan diabetic rabbits. J. Ethnopharmacol. 2007, 110, 498-503.

16. Jakubowski, W.; Biliński, T.; Bartosz, G. Oxidative stress during aging of stationary cultures of the yeast Saccharomyces cerevisiae. Free Radic. Biol. Med. 2000, 28, 659-664.

17. Manfredini, V.; Roehrs, R.; Peralba, M.C.R.; Henriques, J.A.P.; Saffi, J.; Ramos, A.L.L.P.; Benfato, M.S. Glutathione peroxidase induction protects Saccharomyces cerevisiae sod1deltasod2delta double mutants against oxidative damage. Braz. J. Med. Biol. Res. 2004, 37, $159-165$. 
18. Longo, V.D.; Gralla, E.B.; Valentine, J.S. Superoxide dismutase activity is essential for stationary phase survival in Saccharomyces cerevisiae. Mitochondrial production of toxic oxygen species in vivo. J. Biol. Chem. 1996, 271, 12275-12280.

19. Tsuzi, D.; Maeta, K.; Takatsume, Y.; Izawa, S.; Inoue, Y. Regulation of the yeast phospholipid hydroperoxide glutathione peroxidase GPX2 by oxidative stress is mediated by Yap1 and Skn7. FEBS Lett. 2004, 565, 148-154.

20. Inoue, Y.; Matsuda, T.; Sugiyama, K.; Izawa, S.; Kimura, A. Genetic analysis of glutathione peroxidase in oxidative stress response of Saccharomyces cerevisiae. J. Biol. Chem. 1999, 274, 27002-27009.

21. FINNIGAN Xcalibur, release 1.2; ThermoQuest Corporation: San Jose, CA, USA, 2000.

22. NIST/EPA/NIH Mass Spectral Library; John Wiley \& Sons: Hoboken, NJ, USA, 2008.

23. Adams, R.P. Identification of Essential Oil Components by Gas Chromatography/Quadrupole Mass Spectroscopy; Allured Pub. Corp.: Carol Stream, IL, USA, 2001.

24. König, W.A.; Joulain, D.; Hochmuth, D.H. Terpenoids and Related Constituents of Essential Oils. Available online: http://massfinder.com/wiki/Terpenoids_Library (accessed on 12 February 2014).

25. Davies, N. Gas chromatographic retention indices of monoterpenes and sesquiterpenes on methyl silicon and Carbowax 20 M phases. J. Chromatogr. 1990, 503, 1-24.

26. Mensor, L.L.; Menezes, F.S.; Leitão, G.G.; Reis, A.S.; dos Santos, T.C.; Coube, C.S.; Leitão, S.G. Screening of Brazilian plant extracts for antioxidant activity by the use of DPPH free radical method. Phytother. Res. 2001, 15, 127-130.

27. Halliwell, B.; Gutteridge, J.M.; Aruoma, O.I. The deoxyribose method: A simple "test-tube" assay for determination of rate constants for reactions of hydroxyl radicals. Anal. Biochem. 1987, $165,215-219$.

28. Robak, J.; Gryglewski, R.J. Flavonoids are scavengers of superoxide anions. Biochem. Pharmacol. 1988, 37, 837-841.

29. Yen, G.-C.; Chang, Y.-C.; Su, S.-W. Antioxidant activity and active compounds of rice koji fermented with Aspergillus candidus. Food Chem. 2003, 83, 49-54.

30. Zainol, M.K.; Abd-Hamid, A.; Yusof, S.; Muse, R. Antioxidative activity and total phenolic compounds of leaf, root and petiole of four accessions of Centella asiatica (L.) Urban. Food Chem. 2003, 81, 575-581.

31. Romero, A.M.; Doval, M.M.; Sturla, M.A.; Judis, M.A. Antioxidant properties of polyphenol-containing extract from soybean fermented with Saccharomyces cerevisiae. Eur. J. Lipid Sci. Technol. 2004, 106, 424-431.

32. Lowry, O.H.; Rosebrough, N.J.; Farr, A.L.; Randall, R.J. Protein measurement with the folin phenol reagent. J. Biol. Chem. 1951, 193, 265-275.

33. Beauchamp, C.; Fridovich, I. Superoxide dismutase: Improved assays and an assay applicable to acrylamide gels. Anal. Biochem. 1971, 44, 276-287.

34. Carrillo, M.C.; Kanai, S.; Nokubo, M.; Kitani, K. (-) Deprenyl induces activities of both superoxide dismutase and catalase but not of glutathione peroxidase in the striatum of young male rats. Life Sci. 1991, 48, 517-521.

35. Paglia, D.E.; Valentine, W.N. Studies on the quantitative and qualitative characterization of erythrocyte glutathione peroxidase. J. Lab. Clin. Med. 1967, 70, 158-169. 
36. MATLAB, version 6.5.1.; MathWorks Inc.: Natick, MA, USA, 2003.

37. Orav, A.; Koel, M.; Kailas, T.; Müürisepp, M. Comparative analysis of the composition of essential oils and supercritical carbon dioxide extracts from the berries and needles of Estonian juniper (Juniperus communis L.). Procedia Chem. 2010, 2, 161-167.

38. Foti, M.C.; Daquino, C.; Geraci, C. Electron-transfer reaction of cinnamic acids and their methyl esters with the DPPH ${ }^{\circ}$ radical in alcoholic solutions. J. Org. Chem. 2004, 69, 2309-2314.

39. Huang, D.; Ou, B.; Prior, R.L. The chemistry behind antioxidant capacity assays. J. Agric. Food Chem. 2005, 53, 1841-1856.

40. Srinivasan, C.; Liba, A.; Imlay, J.A.; Valentine, J.S.; Gralla, E.B. Yeast lacking superoxide dismutase(s) show elevated levels of "free iron" as measured by whole cell electron paramagnetic resonance. J. Biol. Chem. 2000, 275, 29187-29192.

41. Rudbäck, J.; Bergström, M.A.; Börje, A.; Nilsson, U.; Karlberg, A.-T. $\alpha$-Terpinene, an antioxidant in tea tree oil, autoxidizes rapidly to skin allergens on air exposure. Chem. Res. Toxicol. 2012, 25, $713-721$.

42. Gülçin, İ.; Elmastaş, M.; Aboul-Enein, H.Y. Antioxidant activity of clove oil-A powerful antioxidant source. Arab. J. Chem. 2012, 5, 489-499.

43. MacDonald-Wicks, L.K.; Wood, L.G.; Garg, M.L. Methodology for the determination of biological antioxidant capacity in vitro: A review. J. Sci. Food Agric. 2006, 86, 2046-2056.

44. Clarkson, P.M.; Thompson, H.S. Antioxidants: What role do they play in physical activity and health? Am. J. Clin. Nutr. 2000, 72, 637S-646S.

45. Schüller, C.; Brewster, J.L.; Alexander, M.R.; Gustin, M.C.; Ruis, H. The HOG pathway controls osmotic regulation of transcription via the stress response element (STRE) of the Saccharomyces cerevisiae CTT1 gene. EMBO J. 1994, 13, 4382-4389.

46. Jamieson, D.J.; Rivers, S.L.; Stephen, D.W. Analysis of Saccharomyces cerevisiae proteins induced by peroxide and superoxide stress. Microbiology 1994, 140, 3277-3283.

47. Avery, A.M.; Avery, S.V. Saccharomyces cerevisiae expresses three phospholipid hydroperoxide glutathione peroxidases. J. Biol. Chem. 2001, 276, 33730-33735.

48. Schauss, A.G.; Wu, X.; Prior, R.L.; Ou, B.; Huang, D.; Owens, J.; Agarwal, A.; Jensen, G.S.; Hart, A.N.; Shanbrom, E. Antioxidant capacity and other bioactivities of the freeze-dried Amazonian palm berry, Euterpe oleraceae mart. (Acai). J. Agric. Food Chem. 2006, 54, 8604-8610.

49. Parveen, M.; Hasan, M.K.; Takahashi, J.; Murata, Y.; Kitagawa, E.; Kodama, O.; Iwahashi, H. Response of Saccharomyces cerevisiae to a monoterpene: Evaluation of antifungal potential by DNA microarray analysis. J. Antimicrob. Chemother. 2004, 54, 46-55.

(C) 2014 by the authors; licensee MDPI, Basel, Switzerland. This article is an open access article distributed under the terms and conditions of the Creative Commons Attribution license (http://creativecommons.org/licenses/by/3.0/). 